\title{
Pawel Bartkowiak
}

Uniwersytet Ekonomiczny w Poznaniu

e-mail: pawel.bartkowiak@ue.poznan.pl

\section{PROCES WSPÓŁKREOWANIA WARTOŚCI DLA KLIENTA ZE WZGLĘDU NA ZNACZENIE WYBRANYCH GRUP INTERESARIUSZY}

\section{CONSUMER VALUE-CO-CREATION \\ PROCESS DUE TO THE IMPORTANCE OF SELECTED STAKEHOLDERS}

DOI: $10.15611 /$ pn.2018.538.02

JEL Classification: M30

Streszczenie: Celem opracowania jest ocena procesu współkreowania wartości dla klienta ze względu na znaczenie wybranych grup interesariuszy. W pierwszej części scharakteryzowano proces współkreowania wartości dla klienta, w drugiej zaprezentowano wyniki badań empirycznych przeprowadzonych w polskich przedsiębiorstwach zatrudniających powyżej 49 osób w zakresie roli wybranych grup interesariuszy w procesie współkreowania wartości dla klienta. Prezentacja wyników obejmuje charakterystykę procesu współkreowania wartości dla klienta w obszarach: 1) znaczenia procesu współkreowania wartości dla klienta, 2) intensywności interakcji przedsiębiorstwa z klientami, 3) przydatności zasobów klienta, 4) potencjalnego ryzyka (zagrożeń lub szans), 5) przydatności kanałów komunikacji z klientami oraz 6) determinant oferty przedsiębiorstwa w świetle znaczenia wybranych grup interesariuszy. Do oceny znaczenia interesariuszy wykorzystano test t dla grup niezależnych. Wyniki wskazują na częstość i obszary występowania różnic w badanym procesie ze względu na rolę interesariuszy.

Słowa kluczowe: wartość dla klienta, współkreowanie wartości dla klienta, interesariusze.

Summary: The aim of the article is the evaluation of customer value-co-creation due to the importance of selected company's stakeholders. In the first part of the article value-co-creation process is presented. In the second part of the article the results of empirical research, conducted amongst companies with more than 49 employees, showing the value-co-creation process in the light of the role of selected stakeholders are shown. Results presentation contains the following research areas: (1) importance of value-co-creation process, (2) interaction intensity between company and customers, (3) usefulness of customers' resources, (4) risk (threats or opportunities) of value-co-creation process, (5) usefulness of communication channels and (6) purchase determinants of company's offer in the light of the role of selected stakeholders in value-co-creation process. To evaluate the role of stakeholders test $t$ for independent groups was used. The obtained results indicate the frequency and areas of occurrence of differences in the analyzed process due to the role of stakeholders.

Keywords: value for the customer, value-co-creation, stakeholders. 


\section{Wstęp. Proces współkreowania wartości dla klienta}

Istota współkreowania wartości dla klienta (value-co-creation) sprowadza się do tworzenia oraz zarządzania wartościami dla klienta przez organizację wspólnie z jej interesariuszami [Rampen 2014]. Współkreowanie wartości dla klienta jest więc procesem, w którym różne podmioty systematycznie współdziałają, uczą się i dzielą zasobami w celu tworzenia wartości dla klienta [Prahalad, Ramaswamy 2004; Vargo, Lusch 2004]. W tym kontekście idea współkreowania wartości wydaje się połączeniem dwóch koncepcji - kapitału społecznego, rozumianego przez pryzmat jakości społecznych relacji, opartych na procesach partycypacyjnych, w których różne podmioty wspólnie tworzą i rozwijają ofertę organizacji [Ind, Coates 2013], oraz produktywności wiedzy, rozumianej jako pozyskiwanie nowej wiedzy w celu tworzenia nowych produktów lub procesów [Ehlen i in. 2017].

Proces współkreowania wartości dla klienta nie jest jednorodny i ewoluuje w poszczególnych fazach relacji - pozyskiwania, stabilizowania oraz wzmacniania - występujących między zaangażowanymi podmiotami [Payne i in. 2009]. Na każdym etapie relacji poziom systemowego współkreowania rośnie wraz z rosnącym doświadczeniem zaangażowanych stron - przyczynia się to do bardziej przejrzystego dialogu występującego między równorzędnymi partnerami relacji [Prahalad, Ramaswamy 2004].

Relacje współkreowania wartości dla klienta charakteryzują się wielokierunkowością związaną z zaangażowaniem różnych rodzajów interesariuszy oraz dynamiką, co jest rezultatem przede wszystkim zaangażowania odmiennych zasobów oraz realizacji różnych, często przeciwstawnych celów [Kennedy 2017]. Ostatecznie w procesie współkreowania wartości dla klienta rozwijane są metody interakcji oraz współkształtowania oczekiwań konsumentów, co często prowadzi do dynamicznego tworzeniea się unikatowych stowarzyszeń, determinujących tożsamość organizacji lub marki [Vallaster, von Wallpach 2013].

Interesariusze odgrywają istotną rolę jako podmioty uczestniczące w tworzeniu wartości dla klienta i współdecydujące o tej wartości bądź będące beneficjentami wymiany wartości między organizacją a jej klientami [Dąbrowski 2015]. Interesariusze mogą być różnie definiowani - węższe ujęcie zalicza do nich osoby lub grupy, które w sposób uzasadniony są zainteresowane proceduralnymi i/lub rzeczowymi aspektami działalności przedsiębiorstwa, z kolei szersze uwzględnia podmioty, które poprzez realizację procesu wymiany wpływają na działalność przedsiębiorstwa i same podlegają jego wpływowi [Piwoni-Krzeszowska 2013]. Do najważniejszych interesariuszy zaliczyć więc można dostawców, pośredników biznesowych i pracowników, których rola jest szczególnie podkreślana w marketingu usług i marketingu wewnętrznym [Doyle 1995; Berry 1981], oraz konkurentów i klientów, których znaczenie jest podkreślane m.in. w marketingu relacyjnym [Payne 1999] i w marketingu wartości [Doyle 2008; Dąbrowski 2015]. Powoduje to, że współkreowanie wartości dla klienta odbywa się między sieciami interesariuszy, a nie tylko w tradycyjnym, dualnym układzie organizacja-klient [Grandy, Levit 2015], oraz wskazuje na występowanie 
szerokiego ekosystemu współtworzenia wartości dla klienta, w którym występuje partnerstwo przedsiębiorstwa z konsumentami i/lub innymi grupami interesariuszy [Prahalad, Ramaswamy 2004; Priem 2007].

Efektywność procesu współkreowania wartości dla klienta jest uzależniona od kilku czynników, przyczyniających się do promowania uczestnictwa w tym procesie różnych grup interesariuszy. Wśród tych czynników szczególną uwagę należy zwrócić na zróżnicowaną i zaangażowaną społeczność podmiotów wewnątrz i na zewnętrz organizacji, fizyczną lub wirtualną platformę otwartej dyskusji, stanowiącej bazę komunikacji (generowania oraz wartościowania pomysłów lub projektów) dla tej społeczności, opracowany zestaw skutecznych i efektywnych sposobów interakcji z interesariuszami, perspektywę zindywidualizowania doświadczeń każdej z zainteresowanych stron oraz możliwość tworzenia nowej wartości w sieci przez wszystkie zaangażowane podmioty [Gouillart 2014].

Współkreowanie wartości dla klienta jest więc procesem zróżnicowanym i wielowymiarowym - wpływają na niego przede wszystkim rodzaje zaangażowanych podmiotów, intensywność i typy występujących między nimi interakcji, wachlarz zasobów angażowanych w badany proces, specyfika realizowanych celów oraz rozwiązywanych wspólnie problemów, źródła motywacji oraz mechanizmy współpracy [Roser i in. 2013].

\section{Proces współkreowania wartości dla klienta z perspektywy roli wybranych grup interesariuszy}

Głównym celem opracowania jest ocena wybranych obszarów procesu współkreowania wartości dla klienta z perspektywy polskich przedsiębiorstw ze względu na rolę wybranych grup interesariuszy w badanym procesie. Źródłem oceny są wyniki badań empirycznych zrealizowanych $\mathrm{w}$ drugiej połowie 2015 r. ${ }^{1}$ Elementy poddane ocenie w ramach wybranych obszarów procesu współkreowania wartości dla klienta zostały zidentyfikowane za pomocą metody grup fokusowych, a finalne zbiory zmiennych ustalone za pomocą metody ekspertów. Pozwoliło to na identyfikację i weryfikację następujących obszarów w ramach współkreowania wartości dla klienta, których pomiaru dokonano za pomocą skali Likerta:

- natężenie charakterystyk procesu współkreowania wartości dla klienta z perspektywy przedsiębiorstwa;

- rola interakcji przedsiębiorstwa z klientami w wybranych obszarach funkcjonowania przedsiębiorstwa;

\footnotetext{
${ }^{1}$ Badania przeprowadzone w ramach badań statutowych Katedry Zarządzania Strategicznego Uniwersytetu Ekonomicznego w Poznaniu. Zakresy badań empirycznych: 1) podmiotowy - menedżerowie najwyższego szczebla kierownictwa przedsiębiorstw zatrudniających ponad 49 osób, 2) przedmiotowy - uwarunkowania wyborów strategicznych, 3) przestrzenny - Polska, 4) czasowy - druga połowa 2015 r. Wielkość próby badawczej - 269 respondentów.
} 
- przydatność zasobów klienta w przygotowaniu lub modyfikacji oferty przedsiębiorstwa;

- ocena ryzyka (zagrożeń lub szans) związanego z procesem współkreowania wartości dla klienta wspólnie z interesariuszami;

- weryfikacja utylitarności wybranych kanałów komunikacji przedsiębiorstwa z klientami;

- ocena znaczenia determinant procesu współkreowania wartości wspólnie z klientami.

Podczas oceny znaczenia wybranych grup interesariuszy w procesie współkreowania wartości dla klienta empirycznej weryfikacji poddano następujące podmioty: pracowników, klientów, dostawców, partnerów biznesowych oraz konkurentów. Pomiaru znaczenia dokonano na skali Likerta, gdzie wartość (1) oznaczała brak lub minimalne znaczenie interesariusza $\mathrm{w}$ procesie przygotowania lub modyfikacji oferty przedsiębiorstwa, wartość (2) małe znaczenie, wartość (3) duże znaczenie, natomiast wartość (4) kluczową rolę interesariuszy. Następnie badane grupy interesariuszy podzielone zostały na dwie grupy - do pierwszej zakwalifikowano tych, których znaczenie oceniono jako małe lub niskie, natomiast do drugiej interesariuszy o dużym lub kluczowym znaczeniu (rys. 1).
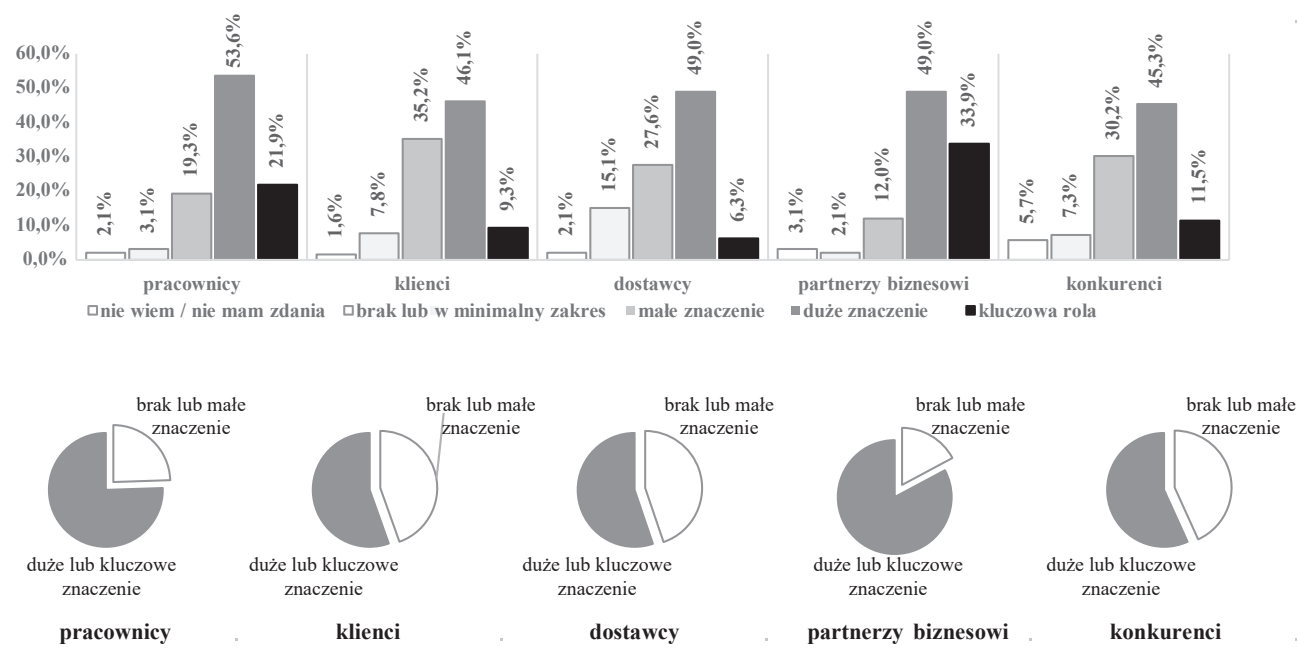

Rys. 1. Znaczenie wybranych grup interesariuszy w procesie przygotowania lub modyfikacji oferty przedsiębiorstwa

Źródło: opracowanie własne na podstawie przeprowadzonych badań empirycznych.

Analiza uzyskanych wyników pozwala na hierarchizację wyodrębnionych grup interesariuszy z perspektywy ich znaczenia w procesie współkreowania wartości dla klienta. W tym kontekście respondenci wskazali w pierwszej kolejności na partnerów biznesowych ( $82,8 \%$ wskazań) oraz pracowników (75,5\% wskazań). Ocena przydatności pozostałych grup interesariuszy jest niższa i kształtuje się na porównywalnym 
poziomie - konkurenci (56,8\% wskazań), klienci (55,4\% wskazań) oraz dostawcy (55,2\% wskazań). Szczególną uwagę zwrócić należy na relatywnie niskie znaczenie klientów oraz dostawców (porównywalne do roli konkurentów), co świadczyć może o braku wypracowanych mechanizmów i zasad angażowania tych grup interesariuszy w procesie współkreowania wartości dla klienta, który powinien być organizowany i nadzorowany przez przedsiębiorstwo.

Do oceny znaczenia wyodrębnionych obszarów procesu współkreowania wartości dla klienta, ze względu na rolę wybranych grup interesariuszy, wykorzystano test $\mathrm{t}$ dla grup niezależnych ${ }^{2}$. Zgodnie $\mathrm{z}$ wymogami testu t badaną zbiorowość podzielono na dwa zbiory - w pierwszym uwzględniono respondentów oceniających znaczenie interesariuszy jako małe lub nieistotne, natomiast $\mathrm{w}$ drugim podmioty oceniające rolę interesariuszy jako dużą lub kluczową.

W kolejnym kroku postępowania badawczego oceniono znaczenie wybranych obszarów, charakteryzujących proces współkreowania wartości dla klienta w przedsiębiorstwie, ze względu na znaczenie interesariuszy (por. tab. 1).

Tabela 1. Średni poziom natężenia obszarów procesu współkreowania wartości dla klienta oraz częstość jego różnicowania ze względu na znaczenie interesariuszy

\begin{tabular}{|c|c|c|c|c|c|c|c|}
\hline \multirow{2}{*}{$\begin{array}{c}\text { Obszary procesu } \\
\text { współkreowania wartości dla } \\
\text { klienta w przedsiębiorstwie }\end{array}$} & \multirow{2}{*}{ 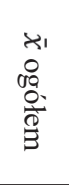 } & \multicolumn{5}{|c|}{ Interesariusze } & \multirow{2}{*}{ 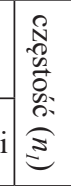 } \\
\hline & & pracownicy & klienci & dostawcy & $\begin{array}{l}\text { partnerzy } \\
\text { biznesowi }\end{array}$ & konkurenci & \\
\hline 1 & 2 & 3 & 4 & 5 & 6 & 7 & 8 \\
\hline $\begin{array}{l}\text { 1. kierownictwo } \\
\text { przedsiębiorstwa } \\
\text { samodzielnie rozwija ofertę } \\
\text { vs. jest otwarte na pomysły } \\
\text { interesariuszy }\end{array}$ & 3,01 & $\begin{array}{l}2,72 \\
3,10 \\
\end{array}$ & $\begin{array}{l}2,85 \\
3,13 \\
\end{array}$ & $\begin{array}{l}2,81 \\
3,16 \\
\end{array}$ & $\begin{array}{l}2,67 \\
3,08 \\
\end{array}$ & - & $4 / 5$ \\
\hline $\begin{array}{l}\text { 2. przedsiębiorstwo nie } \\
\text { jest otwarte na 'otwarte } \\
\text { innowacje' vs. jest otwarte }\end{array}$ & 2,96 & - & $\begin{array}{l}2,79 \\
3,10\end{array}$ & - & - & - & $1 / 5$ \\
\hline $\begin{array}{l}\text { 3. zadowolenie klienta jest } \\
\text { niższe vs. wyższe, gdy oferta } \\
\text { jest kreowana wspólnie } \\
\text { z klientami }\end{array}$ & 2,91 & $\begin{array}{l}2,62 \\
2,99\end{array}$ & $\begin{array}{l}2,69 \\
3,08\end{array}$ & $\begin{array}{l}2,65 \\
3,10\end{array}$ & $\begin{array}{l}2,55 \\
2,97\end{array}$ & - & $4 / 5$ \\
\hline $\begin{array}{l}\text { 4. źródła przewagi konkurencyjnej } \\
\text { są rzadsze vs. liczniejsze } \\
\text { w przypadku kreowania oferty } \\
\text { wspólnie z klientami }\end{array}$ & 2,82 & $\begin{array}{l}2,57 \\
2,90\end{array}$ & $\begin{array}{l}2,64 \\
2,96\end{array}$ & $\begin{array}{l}2,56 \\
3,03\end{array}$ & $\begin{array}{l}2,42 \\
2,90\end{array}$ & - & $4 / 5$ \\
\hline
\end{tabular}

${ }^{2}$ Test $\mathrm{t}$ jest metodą oceny różnic między średnimi w dwóch zbiorach - podawany w wynikach testu t poziom 'p' wskazuje na prawdopodobieństwo błędu związanego z przyjęciem hipotezy o istnieniu różnic między średnimi [Wieczorkowska, Wierzbiński 2011]. 
Tabela 1, cd.

\begin{tabular}{|c|c|c|c|c|c|c|c|}
\hline 1 & 2 & 3 & 4 & 5 & 6 & 7 & 8 \\
\hline $\begin{array}{l}\text { 5. nowy produkt jednostronną } \\
\text { vs. wspólną inicjatywą } \\
\text { przedsiębiorstwa i klientów }\end{array}$ & 2,75 & - & - & $\begin{array}{l}2,48 \\
2,95\end{array}$ & $\begin{array}{l}2,15 \\
2,86\end{array}$ & $\begin{array}{l}2,58 \\
2,86\end{array}$ & $3 / 5$ \\
\hline $\begin{array}{l}\text { 6. przeważają zagrożenia } \\
\text { vs. szanse w przypadku } \\
\text { kreowania oferty z klientami }\end{array}$ & 2,73 & $\begin{array}{l}2,38 \\
2,83\end{array}$ & - & $\begin{array}{l}2,43 \\
2,96\end{array}$ & $\begin{array}{l}2,24 \\
2,82\end{array}$ & - & $3 / 5$ \\
\hline $\begin{array}{l}\text { 7. transakcyjne vs. relacyjne } \\
\text { stosunki z klientami }\end{array}$ & 2,70 & $\begin{array}{l}2,32 \\
2,81\end{array}$ & $\begin{array}{l}2,53 \\
2,82\end{array}$ & - & - & - & $2 / 5$ \\
\hline $\begin{array}{l}\text { 8. wartość dla klienta } \\
\text { jest kreowana przez } \\
\text { przedsiębiorstwo } \\
\text { vs. wspólnie z klientami }\end{array}$ & 2,70 & $\begin{array}{l}2,36 \\
2,79\end{array}$ & $\begin{array}{l}2,47 \\
2,87\end{array}$ & $\begin{array}{l}2,47 \\
2,87\end{array}$ & $\begin{array}{l}2,39 \\
2,75\end{array}$ & - & $4 / 5$ \\
\hline $\begin{array}{l}\text { 9. jakość produktów jest niższa } \\
\text { vs. wyższa w przypadku } \\
\text { przygotowania oferty } \\
\text { wspólnie z klientami }\end{array}$ & 2,69 & $\begin{array}{l}2,34 \\
2,79\end{array}$ & $\begin{array}{l}2,47 \\
2,86\end{array}$ & $\begin{array}{l}2,42 \\
2,90\end{array}$ & $\begin{array}{l}2,30 \\
2,76\end{array}$ & - & $4 / 5$ \\
\hline $\begin{array}{l}\text { 10. w przedsiębiorstwie } \\
\text { przeważają hierarchiczne } \\
\text { vs. elastyczne powiązania } \\
\text { organizacyjne }\end{array}$ & 2,64 & - & - & $\begin{array}{l}2,50 \\
2,75\end{array}$ & - & - & $1 / 5$ \\
\hline $\begin{array}{l}\text { 11. oferta rynkowa jest kreowana } \\
\text { jednostronnie vs. we } \\
\text { współpracy z klientami }\end{array}$ & 2,63 & - & $\begin{array}{l}2,42 \\
2,78\end{array}$ & $\begin{array}{l}2,33 \\
2,85\end{array}$ & $\begin{array}{l}2,06 \\
2,73\end{array}$ & - & $3 / 5$ \\
\hline $\begin{array}{l}\text { 12. w firmie nie jest vs. jest } \\
\text { opracowany system motywacji } \\
\text { związany z rozwojem oferty }\end{array}$ & 2,63 & $\begin{array}{l}2,28 \\
2,73\end{array}$ & - & - & $\begin{array}{l}2,12 \\
2,72\end{array}$ & - & $2 / 5$ \\
\hline $\begin{array}{l}\text { 13. przedsiębiorstwo jest } \\
\text { zamknięte vs. otwarte na } \\
\text { współpracę z nieznanymi } \\
\text { interesariuszami }\end{array}$ & 2,62 & - & - & $\begin{array}{l}2,47 \\
2,74\end{array}$ & - & - & $1 / 5$ \\
\hline $\begin{array}{l}\text { 14. oferta rynkowa jest } \\
\text { przygotowywana } \\
\text { przez przedsiębiorstwo } \\
\text { vs. } \mathrm{z} \text { kooperantami }\end{array}$ & 2,56 & $\begin{array}{l}2,26 \\
2,65\end{array}$ & $\begin{array}{l}2,37 \\
2,70\end{array}$ & $\begin{array}{l}2,26 \\
2,79\end{array}$ & $\begin{array}{l}2,03 \\
2,66\end{array}$ & $\begin{array}{l}2,39 \\
2,68\end{array}$ & $5 / 5$ \\
\hline $\begin{array}{l}\text { 15. współpraca z klientami } \\
\text { nie ułatwia vs. ułatwia } \\
\text { personalizację produktów }\end{array}$ & 2,54 & $\begin{array}{l}2,21 \\
2,63 \\
\end{array}$ & $\begin{array}{l}2,37 \\
2,66\end{array}$ & $\begin{array}{l}2,38 \\
2,65\end{array}$ & - & - & $3 / 5$ \\
\hline $\begin{array}{l}\text { 16. w rozwoju produktów } \\
\text { wykorzystywane są wewnętrzne } \\
\text { vs. zewnętrzne zasoby }\end{array}$ & 2,33 & $\begin{array}{l}1,89 \\
2,46\end{array}$ & $\begin{array}{l}2,14 \\
2,47\end{array}$ & $\begin{array}{l}2,15 \\
2,46\end{array}$ & - & - & $3 / 5$ \\
\hline \multicolumn{2}{|c|}{ częstość różnicowania $\left(n_{2}\right)$} & $11 / 16$ & $11 / 16$ & $13 / 16$ & $10 / 16$ & $2 / 16$ & \\
\hline
\end{tabular}

Legenda: pomiar dokonany na czterostopniowej skali Likerta, gdzie: 1) brak lub w minimalnym zakresie, 2) małe znaczenie, 3) duże znaczenie, 4) kluczowe znaczenie oraz 0) nie wiem/nie mam zdania. Źródło: opracowanie własne na podstawie przeprowadzonych badań empirycznych. 
Analiza uzyskanych wyników (por. tab. 1) pozwala na hierarchizację znaczenia wyodrębnionych obszarów procesu współkreowania wartości dla klienta ( $\bar{x}$ ogółem) oraz wskazanie tych, w zakresie których zidentyfikowano różnice w średnich, ze względu na rolę interesariuszy. Do obszarów o najwyższym znaczeniu zaliczyć należy przede wszystkim: otwartość przedsiębiorstwa na pomysły interesariuszy $(\bar{x}=3,01)$, „otwarte innowacje" $(\bar{x}=2,96)$ oraz występowanie wyższego zadowolenia klienta, gdy oferta jest współkreowana $(\bar{x}=2,91)$. $Z$ kolei do obszarów, w których zakresie zidentyfikowano najwięcej różnic $\left(n_{l} \geq 4 / 5\right)$ ze względu na rolę wyodrębnionych grup interesariuszy, zaliczają się:

a) w przypadku dużej lub kluczowej roli każdej z badanych grup interesariuszy $\left(n_{1}=5 / 5\right)$ :

- przygotowywanie oferty rynkowej wspólnie z kooperantami,

b) w przypadku dużej lub kluczowej roli pracowników, klientów, dostawców i partnerów biznesowych $\left(n_{l}=4 / 5\right)$ :

- kreowanie wartości dla klienta wspólnie z klientami,

- wyższa jakość produktów,

- wyższe zadowolenie klienta z oferty rynkowej,

- liczniejsze źródła przewagi konkurencyjnej,

- otwartość kierownictwa na pomysły interesariuszy.

Uzyskane wyniki wskazują jednoznacznie na występowanie wyższego natężenia obszarów procesu współkreowania wartości dla klienta w sytuacji dużej lub kluczowej roli wyodrębnionych grup interesariuszy. Do interesariuszy, w których przypadku częstość różnicowania obszarów badanego procesu jest największa, zaliczają się: dostawcy $\left(n_{2}=13 / 16\right)$, pracownicy $\left(n_{2}=11 / 16\right)$, klienci $\left(n_{2}=11 / 16\right)$ oraz partnerzy biznesowi $\left(n_{2}=10 / 16\right)$ - rola konkurentów jest w tym przypadku minimalna.

Tabela 2. Średni poziom intensywności interakcji z klientami w wybranych obszarach procesu współkreowania wartości dla klienta oraz częstość jego różnicowania ze względu na znaczenie interesariuszy

\begin{tabular}{|c|c|c|c|c|c|c|c|}
\hline \multirow{2}{*}{$\begin{array}{c}\text { Obszary funkcjonowania } \\
\text { przedsiębiorstwa }\end{array}$} & \multirow{2}{*}{ 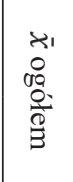 } & \multicolumn{5}{|c|}{ Interesariusze } & \multirow{2}{*}{ 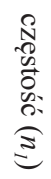 } \\
\hline & & pracownicy & klienci & dostawcy & $\begin{array}{l}\text { partnerzy } \\
\text { biznesowi }\end{array}$ & konkurenci & \\
\hline 1 & 2 & 3 & 4 & 5 & 6 & 7 & 8 \\
\hline $\begin{array}{l}\text { 1. rozwój lub modyfikacja } \\
\text { koncepcji produktu }\end{array}$ & 2,61 & $\begin{array}{l}2,40 \\
2,69\end{array}$ & $\begin{array}{l}2,40 \\
2,80\end{array}$ & $\begin{array}{l}2,35 \\
2,83\end{array}$ & $\begin{array}{l}1,91 \\
2,77\end{array}$ & $\begin{array}{l}2,45 \\
2,75\end{array}$ & $5 / 5$ \\
\hline $\begin{array}{l}\text { 2. określenie finalnej } \\
\text { wersji produktu (przed } \\
\text { komercjalizacją) }\end{array}$ & 2,42 & $\begin{array}{l}1,88 \\
2,60\end{array}$ & - & $\begin{array}{l}2,15 \\
2,64\end{array}$ & $\begin{array}{l}1,65 \\
2,59\end{array}$ & $\begin{array}{l}2,18 \\
2,61\end{array}$ & $4 / 5$ \\
\hline $\begin{array}{l}\text { 3. udział w promocji } \\
\text { produktu }\end{array}$ & 2,33 & $\begin{array}{l}1,77 \\
2,52\end{array}$ & $\begin{array}{l}2,16 \\
2,47\end{array}$ & - & $\begin{array}{l}1,82 \\
2,44\end{array}$ & $\begin{array}{l}2,16 \\
2,47\end{array}$ & $4 / 5$ \\
\hline $\begin{array}{l}\text { 4. uczestnictwo w procesie } \\
\text { dystrybucji produktu }\end{array}$ & 2,28 & $\begin{array}{l}1,74 \\
2,44\end{array}$ & $\begin{array}{l}2,10 \\
2,48\end{array}$ & - & $\begin{array}{l}1,65 \\
2,40\end{array}$ & $\begin{array}{l}1,98 \\
2,50\end{array}$ & $4 / 5$ \\
\hline
\end{tabular}


Tabela 2, cd.

\begin{tabular}{|l|c|c|c|c|c|c|c|}
\hline 1 & 2 & 3 & 4 & 5 & 6 & 7 & 8 \\
\hline $\begin{array}{l}\text { 5. partycypacja w procesie } \\
\text { produkcyjnym }\end{array}$ & & & & & & & \\
(podwykonawca, & & & 1,92 & 1,85 & 1,32 & 1,88 & \\
współproducent) & $\mathbf{2 , 1 1}$ & - & 2,25 & 2,31 & 2,27 & 2,28 & $\mathbf{4 / 5}$ \\
\hline częstość różnicowania $\left(n_{2}\right)$ & $\mathbf{4 / 5}$ & $\mathbf{4 / 5}$ & $\mathbf{3 / 5}$ & $\mathbf{5 / 5}$ & $\mathbf{5 / 5}$ & \\
\hline
\end{tabular}

Legenda: pomiar dokonany na czterostopniowej skali Likerta, gdzie: 1) brak lub w minimalnym zakresie, 2) mała intensywność, 3) duża intensywność, 4) kluczowa rola interesariuszy oraz 0) nie wiem /nie mam zdania.

Źródło: opracowanie własne na podstawie przeprowadzonych badań empirycznych.

Następnie oceniono intensywność interakcji z klientami w wybranych obszarach funkcjonowania przedsiębiorstwa związanych ze współkreowaniem wartości dla klienta, z uwzględnieniem roli wyodrębnionych grup interesariuszy (por. tab. 2).

Wyniki zaprezentowane w tabeli 2 wskazują na rozwój lub modyfikację produktu $(\bar{x}=2,61)$ oraz określenie finalnej wersji produktu przed komercjalizacją $(\bar{x}=2,42)$ jako obszary najistotniejsze z perspektywy interakcji z klientami w procesie współkreowania wartości. Zwrócić należy uwagę na częstość różnicowania badanych obszarów interakcji z klientami ze względu na rolę (znaczenie) wyodrębnionych grup interesariuszy $\left(n_{1} \geq 4 / 5\right)$ oraz częstość różnicowania tych obszarów w poszczególnych grupach interesariuszy $\left(n_{2} \geq 3 / 5\right)$ - średni poziom znaczenia tych interakcji jest każdorazowo wyższy w przypadku dużej lub kluczowej roli wyodrębnionych grup interesariuszy.

W następnej kolejności oceniono przydatność wybranych zasobów klienta w procesie przygotowania lub modyfikacji oferty przedsiębiorstwa ze względu na znaczenie wyodrębnionych grup interesariuszy (por. tab. 3).

Tabela 3. Średnia przydatność wybranych zasobów klienta oraz częstość jej różnicowania w procesie przygotowania lub modyfikacji oferty przedsiębiorstwa ze względu na znaczenie interesariuszy

\begin{tabular}{|c|c|c|c|c|c|c|c|}
\hline \multirow{2}{*}{ Zasoby klienta } & \multirow{2}{*}{ 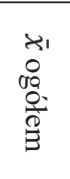 } & \multicolumn{5}{|c|}{ Interesariusze } & \multirow{2}{*}{ 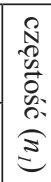 } \\
\hline & & pracownicy & klienci & dostawcy & $\begin{array}{l}\text { partnerzy } \\
\text { biznesowi }\end{array}$ & konkurenci & \\
\hline 1 & 2 & 3 & 4 & 5 & 6 & 7 & 8 \\
\hline $\begin{array}{l}\text { 1. informacje o potrzebach } \\
\text { klienta }\end{array}$ & 3,66 & - & $\begin{array}{l}3,52 \\
3,74\end{array}$ & $\begin{array}{l}3,53 \\
3,73\end{array}$ & $\begin{array}{l}3,35 \\
3,70\end{array}$ & - & $3 / 5$ \\
\hline $\begin{array}{l}\text { 2. doświadczenia i wrażenia } \\
\text { z użytkowania produktu } \\
\text { przez klienta (oceny, } \\
\text { uwagi, sugestie) }\end{array}$ & 3,42 & $\begin{array}{l}3,06 \\
3,53\end{array}$ & $\begin{array}{l}3,17 \\
3,64\end{array}$ & $\begin{array}{l}3,30 \\
3,54\end{array}$ & $\begin{array}{l}3,12 \\
3,50\end{array}$ & - & $4 / 5$ \\
\hline $\begin{array}{l}\text { 3. spostrzeżenia/sugestie } \\
\text { dotyczace postrzeganej } \\
\text { wartości produktu }\end{array}$ & 3,36 & $\begin{array}{l}2,98 \\
3,48\end{array}$ & - & $\begin{array}{l}3,18 \\
3,49\end{array}$ & $\begin{array}{l}2,94 \\
3,44\end{array}$ & - & $3 / 5$ \\
\hline
\end{tabular}




\begin{tabular}{|c|c|c|c|c|c|c|c|}
\hline 1 & 2 & 3 & 4 & 5 & 6 & 7 & 8 \\
\hline $\begin{array}{l}\text { 4. referencje i rekomendacje } \\
\text { klientów (lojalność, } \\
\text { przychylność, zaufanie) }\end{array}$ & 3,33 & $\begin{array}{l}2,96 \\
3,49\end{array}$ & $\begin{array}{l}3,03 \\
3,61\end{array}$ & $\begin{array}{l}3,16 \\
3,52\end{array}$ & $\begin{array}{l}2,79 \\
3,48\end{array}$ & $\begin{array}{l}3,22 \\
3,47\end{array}$ & $5 / 5$ \\
\hline $\begin{array}{l}\text { 5. informacje o postrzeganiu } \\
\text { rynku }\end{array}$ & 3,24 & $\begin{array}{l}3,00 \\
3,32\end{array}$ & $\begin{array}{l}3,09 \\
3,35\end{array}$ & $\begin{array}{l}3,12 \\
3,33\end{array}$ & $\begin{array}{l}2,97 \\
3,29\end{array}$ & - & $4 / 5$ \\
\hline $\begin{array}{l}\text { 6. informacje o finansowych } \\
\text { możliwościach klienta } \\
\text { (szacowanie potencjału) }\end{array}$ & 3,15 & - & - & $\begin{array}{l}2,94 \\
3,29 \\
\end{array}$ & $\begin{array}{l}2,74 \\
3,22 \\
\end{array}$ & $\begin{array}{l}2,91 \\
3,31 \\
\end{array}$ & $3 / 5$ \\
\hline $\begin{array}{l}\text { 7. propozycje nowych lub } \\
\text { modernizacji istniejących } \\
\text { produktów }\end{array}$ & 3,11 & $\begin{array}{l}2,75 \\
3,21 \\
\end{array}$ & $\begin{array}{l}2,89 \\
3,28 \\
\end{array}$ & $\begin{array}{l}2,85 \\
3,30 \\
\end{array}$ & $\begin{array}{l}2,62 \\
3,20 \\
\end{array}$ & $\begin{array}{l}2,87 \\
3,28 \\
\end{array}$ & $5 / 5$ \\
\hline $\begin{array}{l}\text { 8. testowanie } \\
\text { produktu / rozwiązań } \\
\text { technologicznych (ocena } \\
\text { nowych propozycji) }\end{array}$ & 3,07 & $\begin{array}{l}2,48 \\
3,22 \\
\end{array}$ & $\begin{array}{l}2,75 \\
3,27 \\
\end{array}$ & - & $\begin{array}{l}2,50 \\
3,15 \\
\end{array}$ & $\begin{array}{l}2,83 \\
3,20 \\
\end{array}$ & $4 / 5$ \\
\hline $\begin{array}{l}\text { 9. informacje o preferencjach } \\
\text { (motywach, } \\
\text { upodobaniach) klienta }\end{array}$ & 2,82 & $\begin{array}{l}2,21 \\
2,99 \\
\end{array}$ & $\begin{array}{l}2,59 \\
2,96 \\
\end{array}$ & $\begin{array}{l}2,53 \\
3,01 \\
\end{array}$ & $\begin{array}{l}2,32 \\
2,89\end{array}$ & $\begin{array}{l}2,53 \\
3,00 \\
\end{array}$ & $5 / 5$ \\
\hline $\begin{array}{l}\text { 10. informacje o stylu } \\
\text { życia (zwyczajach } \\
\text { konsumenckich), hobby, } \\
\text { pasjach lub inspiracjach } \\
\text { klienta }\end{array}$ & 2,48 & $\begin{array}{l}1,94 \\
2,63\end{array}$ & $\begin{array}{l}2,23 \\
2,64\end{array}$ & $\begin{array}{l}2,13 \\
2,72\end{array}$ & - & $\begin{array}{l}2,20 \\
2,66\end{array}$ & $4 / 5$ \\
\hline \multicolumn{2}{|c|}{ częstość różnicowania $\left(n_{2}\right)$} & $8 / 10$ & 8/10 & 9/10 & 9/10 & $6 / 10$ & \\
\hline
\end{tabular}

Legenda: pomiar dokonany na czterostopniowej skali Likerta, gdzie: 1) zdecydowanie nieprzydatne, 2) mało przydatne, 3) raczej przydatne, 4) zdecydowanie przydatne oraz 0) nie wiem/nie mam zdania.

Źródło: opracowanie własne na podstawie przeprowadzonych badań empirycznych.

Do zasobów klienta ocenionych jako najistotniejsze w procesie współkreowania wartości dla klienta (por. tab. 3) zaliczają się przede wszystkim informacje o potrzebach klienta $(\bar{x}=3,66)$, doświadczenia i wrażenia z użytkowania produktu przez klienta $(\bar{x}=3,42)$, spostrzeżenia i sugestie dotyczące postrzeganej wartości produktu $(\bar{x}=3,36)$ oraz referencje i rekomendacje klientów $(\bar{x}=3,33)$. Do zasobów, których znaczenie jest najczęściej różnicowane ze względu na rolę interesariuszy $\left(n_{l}=5 / 5\right)$, zaliczają się referencje i rekomendacje klientów, propozycje nowych lub modernizacje istniejących produktów oraz informacje o preferencjach klienta - znaczenie tych zasobów jest zawsze wyższe w grupach interesariuszy o dużej lub kluczowej roli. Do interesariuszy, których rola najrzadziej różnicuje badane zasoby klienta, zaliczyć należy konkurentów $\left(n_{2}=6 / 10\right)$; w przypadku pozostałych interesariuszy różnicowanie jest częstsze $\left(n_{2} \geq 8 / 10\right)$.

Następnie oceniono potencjalne ryzyko (zagrożenia oraz szanse) związane z procesem współkreowania wartości w świetle znaczenia wyodrębnionych grup interesariuszy (por. tab. 4). 
Tabela 4. Średni poziom potencjalnego ryzyka związanego z procesem współkreowania wartości oraz częstość jego różnicowania ze względu na znaczenie interesariuszy

\begin{tabular}{|c|c|c|c|c|c|c|c|}
\hline \multirow{2}{*}{ Obszary potencjalnego ryzyka } & \multirow{2}{*}{$\begin{array}{l}21 \\
3 \\
0 \\
0 \\
0 \\
0 \\
0 \\
0\end{array}$} & \multicolumn{5}{|c|}{ Interesariusze } & \multirow{2}{*}{  } \\
\hline & & pracownicy & klienci & dostawcy & $\begin{array}{l}\text { partnerzy } \\
\text { biznesowi }\end{array}$ & konkurenci & \\
\hline $\begin{array}{l}\text { 1. ryzyko spełnienia } \\
\text { oczekiwań potencjalnego } \\
\text { klienta produktu }\end{array}$ & 3,05 & $\begin{array}{l}2,77 \\
3,15\end{array}$ & - & $\begin{array}{l}2,80 \\
3,25\end{array}$ & $\begin{array}{l}2,29 \\
3,22\end{array}$ & $\begin{array}{l}2,88 \\
3,18\end{array}$ & $4 / 5$ \\
\hline $\begin{array}{l}\text { 2. ryzyko zaufania między } \\
\text { podmiotami relacji }\end{array}$ & 2,83 & - & - & - & $\begin{array}{l}2,26 \\
2,95\end{array}$ & $\begin{array}{l}2,64 \\
2,97\end{array}$ & $2 / 5$ \\
\hline $\begin{array}{l}\text { 3. ryzyko zainteresowania } \\
\text { projektem ze strony } \\
\text { potencjalnego klienta (ryzyko } \\
\text { powodzenia projektu) }\end{array}$ & 2,80 & - & $\begin{array}{l}2,44 \\
3,07\end{array}$ & $\begin{array}{l}2,48 \\
3,03\end{array}$ & $\begin{array}{l}2,21 \\
2,91\end{array}$ & $\begin{array}{l}2,47 \\
3,03\end{array}$ & $4 / 5$ \\
\hline $\begin{array}{l}\text { 4. ryzyko wywiązywania się } \\
\text { ze wzajemnych zobowiązań }\end{array}$ & 2,79 & - & $\begin{array}{l}2,55 \\
2,97\end{array}$ & $\begin{array}{l}2,61 \\
2,93\end{array}$ & $\begin{array}{l}2,38 \\
2,87\end{array}$ & $\begin{array}{l}2,63 \\
2,91\end{array}$ & $4 / 5$ \\
\hline $\begin{array}{l}\text { 5. ryzyko intensywności } \\
\text { kontaktów z klientem }\end{array}$ & 2,65 & $\begin{array}{l}2,31 \\
2,74\end{array}$ & - & $\begin{array}{l}2,31 \\
2,90 \\
\end{array}$ & $\begin{array}{l}2,21 \\
2,73\end{array}$ & $\begin{array}{l}2,39 \\
2,83 \\
\end{array}$ & $4 / 5$ \\
\hline $\begin{array}{l}\text { 6. ryzyko finansowego } \\
\text { zaangażowania } \\
\text { przedsiębiorstwa w rozwój } \\
\text { projektu (partycypacja } \\
\text { w kosztach) }\end{array}$ & 2,37 & - & - & $\begin{array}{l}2,13 \\
2,53\end{array}$ & $\begin{array}{l}1,88 \\
2,46\end{array}$ & - & $2 / 5$ \\
\hline $\begin{array}{l}\text { 7. ryzyko jakości interakcji } \\
\text { z klientem (pomijanie, } \\
\text { ignorowanie) }\end{array}$ & 2,33 & $\begin{array}{l}1,81 \\
2,49\end{array}$ & - & - & $\begin{array}{l}1,94 \\
2,41\end{array}$ & - & $2 / 5$ \\
\hline $\begin{array}{l}\text { 8. ryzyko poszanowania prawa } \\
\text { własności do projektu }\end{array}$ & 2,31 & - & $\begin{array}{l}1,94 \\
2,58 \\
\end{array}$ & $\begin{array}{l}2,07 \\
2,48 \\
\end{array}$ & $\begin{array}{l}1,82 \\
2,40 \\
\end{array}$ & $\begin{array}{l}2,00 \\
2,52 \\
\end{array}$ & $4 / 5$ \\
\hline $\begin{array}{l}\text { 9. ryzyko kontroli autora } \\
\text { (klienta) projektu przez } \\
\text { przedsiębiorstwo }\end{array}$ & 2,28 & - & $\begin{array}{l}1,89 \\
2,61\end{array}$ & - & $\begin{array}{l}1,82 \\
2,39\end{array}$ & $\begin{array}{l}2,02 \\
2,50\end{array}$ & $3 / 5$ \\
\hline $\begin{array}{l}\text { 10. ryzyko czasowego } \\
\text { zaangażowania autora } \\
\text { projektu w jego rozwój }\end{array}$ & 2,14 & - & $\begin{array}{l}1,85 \\
2,36\end{array}$ & - & $\begin{array}{l}1,47 \\
2,27\end{array}$ & $\begin{array}{l}1,83 \\
2,36\end{array}$ & $3 / 5$ \\
\hline $\begin{array}{l}\text { 11. ryzyko partycypacji } \\
\text { w komercjalizacji projektu }\end{array}$ & 2,07 & - & - & $\begin{array}{l}1,81 \\
2,26\end{array}$ & $\begin{array}{l}1,41 \\
2,20\end{array}$ & $\begin{array}{l}1,81 \\
2,26\end{array}$ & $3 / 5$ \\
\hline $\begin{array}{l}\text { 12. ryzyko przejęcia projektu } \\
\text { przez konkurenta } \\
\text { (bezpieczeństwa / } \\
\text { poufności projektu) }\end{array}$ & 1,77 & - & - & - & $\begin{array}{l}1,44 \\
1,82 \\
\end{array}$ & - & $1 / 5$ \\
\hline częstość różnicowa1 & $\mathrm{a}\left(n_{2}\right)$ & $3 / 12$ & $5 / 12$ & $7 / 12$ & $12 / 12$ & $9 / 12$ & \\
\hline
\end{tabular}

Legenda: pomiar dokonany na czterostopniowej skali Likerta, gdzie: 1) zdecydowanie zagrożenie, 2) zagrożenie, 3) szansa, 4) zdecydowanie szansa oraz 0) nie wiem/nie mam zdania.

Źródło: opracowanie własne na podstawie przeprowadzonych badań empirycznych. 
Analiza uzyskanych wyników pozwala na identyfikację szans i zagrożeń związanych z procesem współkreowania wartości dla klienta (por. tab. 4). W zbiorze szans wskazać należy zwłaszcza spełnienie oczekiwań potencjalnego klienta $(\bar{x}=3,05)$, zaufanie między podmiotami we współkreowaniu wartości $(\bar{x}=2,83)$, zainteresowanie produktem przez potencjalnego klienta $(\bar{x}=2,80)$ oraz wywiązywanie się ze wzajemnych zobowiązań $(\bar{x}=2,79)$. Z kolei w zbiorze zagrożeń znajdują się przejęcie projektu przez konkurenta $(\bar{x}=1,77)$, partycypacja w komercjalizacji produktu $(\bar{x}=2,07)$ oraz czasowe zaangażowanie autora projektu w jego rozwój $(\bar{x}=2,14)$. Częstość różnicowania badanego ryzyka $\mathrm{w}$ grupach badanych interesariuszy jest najwyższa $\mathrm{w}$ grupach partnerów biznesowych $\left(n_{2}=12 / 12\right)$ oraz konkurentów $\left(n_{2}=9 / 12\right)$ - wyższe wartości średnie, w przypadku ważnych lub kluczowych interesariuszy, świadczą o ich roli w procesach współkreowania wartości dla klienta w badanych przedsiębiorstwach.

Następny krok postępowania badawczego dotyczył oceny przydatności wybranych kanałów komunikacji przedsiębiorstwa z klientami w procesie przygotowywania lub modyfikacji oferty przedsiębiorstwa ze względu na znaczenie interesariuszy (por. tab. 5).

Tabela 5. Średni poziom przydatności wybranych kanałów komunikacji przedsiębiorstwa z klientem w przygotowywaniu lub modyfikacji oferty przedsiębiorstwa oraz częstość jego różnicowania ze względu na znaczenie interesariuszy

\begin{tabular}{|c|c|c|c|c|c|c|c|}
\hline \multirow{2}{*}{$\begin{array}{c}\text { Kanały komunikacji } \\
\text { przedsiębiorstwa z klientem }\end{array}$} & \multirow{2}{*}{ 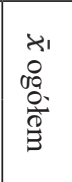 } & \multicolumn{5}{|c|}{ Interesariusze } & \multirow{2}{*}{ 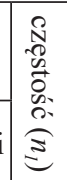 } \\
\hline & & pracownicy & klienci & dostawcy & $\begin{array}{l}\text { partnerzy } \\
\text { biznesowi }\end{array}$ & konkurenci & \\
\hline 1 & 2 & 3 & 4 & 5 & 6 & 7 & 8 \\
\hline $\begin{array}{l}\text { 1. kontakt osobisty } \\
\text { (z pracownikiem lub } \\
\text { menedżerem) }\end{array}$ & 3,64 & $\begin{array}{l}3,44 \\
3,68\end{array}$ & $\begin{array}{l}3,44 \\
3,77\end{array}$ & $\begin{array}{l}3,49 \\
3,72\end{array}$ & $\begin{array}{l}3,35 \\
3,68\end{array}$ & $\begin{array}{l}3,50 \\
3,72\end{array}$ & $5 / 5$ \\
\hline $\begin{array}{l}\text { 2. strona www - formularz } \\
\text { kontaktowy, konto klienta }\end{array}$ & 3,16 & $\begin{array}{l}2,92 \\
3,28\end{array}$ & - & - & $\begin{array}{l}2,79 \\
3,29\end{array}$ & - & $2 / 5$ \\
\hline $\begin{array}{l}\text { 3. targi, wystawy, } \\
\text { pokazy, dni otwarte } \\
\text { w przedsiębiorstwie }\end{array}$ & 2,97 & - & $\begin{array}{l}2,72 \\
3,14\end{array}$ & $\begin{array}{l}2,79 \\
3,08\end{array}$ & $\begin{array}{l}2,62 \\
3,02\end{array}$ & $\begin{array}{l}2,69 \\
3,17\end{array}$ & $4 / 5$ \\
\hline $\begin{array}{l}\text { 4. kontakt telefoniczny } \\
\text { (infolinia, call center, SMS) }\end{array}$ & 2,95 & - & $\begin{array}{l}2,71 \\
3,15\end{array}$ & $\begin{array}{l}2,72 \\
3,14\end{array}$ & - & $\begin{array}{l}2,77 \\
3,10\end{array}$ & $3 / 5$ \\
\hline $\begin{array}{l}\text { 5. punkt obsługi klienta, } \\
\text { punkt reklamacji (serwis) }\end{array}$ & 2,79 & $\begin{array}{l}2,30 \\
2,95\end{array}$ & $\begin{array}{l}2,59 \\
2,96\end{array}$ & $\begin{array}{l}2,60 \\
2,95\end{array}$ & $\begin{array}{l}2,39 \\
2,88\end{array}$ & - & $4 / 5$ \\
\hline $\begin{array}{l}\text { 6. ankieta (sondaż) } \\
\text { internetowy }\end{array}$ & 2,47 & $\begin{array}{l}2,00 \\
2,64\end{array}$ & - & - & $\begin{array}{l}1,85 \\
2,63\end{array}$ & - & $2 / 5$ \\
\hline $\begin{array}{l}\text { 7. ankieta (sondaż) w punkcie } \\
\text { sprzedaży }\end{array}$ & 2,43 & $\begin{array}{l}1,96 \\
2,55\end{array}$ & - & - & $\begin{array}{l}2,06 \\
2,48\end{array}$ & $\begin{array}{l}2,21 \\
2,56\end{array}$ & $3 / 5$ \\
\hline $\begin{array}{l}\text { 8. forum internetowe } \\
\text { (ogólnodostępne, } \\
\text { konsumenckie, blog) }\end{array}$ & 2,27 & $\begin{array}{l}1,75 \\
2,43\end{array}$ & - & - & - & $\begin{array}{l}2,08 \\
2,40\end{array}$ & $2 / 5$ \\
\hline
\end{tabular}


Tabela 5, cd.

\begin{tabular}{|c|c|c|c|c|c|c|c|}
\hline 1 & 2 & 3 & 4 & 5 & 6 & 7 & 8 \\
\hline $\begin{array}{l}\text { 9. internetowy konfigurator } \\
\text { ofert }\end{array}$ & 2,19 & $\begin{array}{l}1,75 \\
2,32\end{array}$ & - & $\begin{array}{l}1,90 \\
2,40\end{array}$ & $\begin{array}{l}1,62 \\
2,29\end{array}$ & $\begin{array}{l}1,82 \\
2,45\end{array}$ & $4 / 5$ \\
\hline $\begin{array}{l}\text { 10. forum internetowe } \\
\text { moderowane przez } \\
\text { producenta }\end{array}$ & 2,16 & $\begin{array}{l}1,77 \\
2,26\end{array}$ & $\begin{array}{l}1,93 \\
2,31\end{array}$ & $\begin{array}{l}1,94 \\
2,30\end{array}$ & $\begin{array}{l}1,76 \\
2,22\end{array}$ & $\begin{array}{l}1,92 \\
2,31\end{array}$ & $5 / 5$ \\
\hline $\begin{array}{l}\text { 11. portal społecznościowy } \\
\text { (Facebook, Twitter itp.) }\end{array}$ & 2,13 & $\begin{array}{l}1,54 \\
2,29\end{array}$ & $\begin{array}{l}1,90 \\
2,27\end{array}$ & - & $\begin{array}{l}1,74 \\
2,18\end{array}$ & $\begin{array}{l}1,91 \\
2,26\end{array}$ & $4 / 5$ \\
\hline $\begin{array}{l}\text { 12. czat / komunikator interneto- } \\
\text { wy / videorozmowa (Skype) }\end{array}$ & 1,95 & $\begin{array}{l}1,35 \\
2,12\end{array}$ & - & - & $\begin{array}{l}1,44 \\
2,04\end{array}$ & $\begin{array}{l}1,67 \\
2,14\end{array}$ & $3 / 5$ \\
\hline $\begin{array}{l}\text { 13. kanał korporacyjny itp. } \\
\text { w serwisie YouTube }\end{array}$ & 1,85 & $\begin{array}{l}1,44 \\
1,97\end{array}$ & - & - & - & $\begin{array}{l}1,56 \\
2,05\end{array}$ & $2 / 5$ \\
\hline \multicolumn{2}{|c|}{ częstość różnicowania $\left(n_{2}\right)$} & $11 / 13$ & $6 / 13$ & $6 / 13$ & $10 / 13$ & $10 / 13$ & \\
\hline
\end{tabular}

Legenda: pomiar dokonany na czterostopniowej skali Likerta, gdzie: 1) zdecydowanie nieprzydatne, 2) mało przydatne, 3) raczej przydatne, 4) zdecydowanie przydatne oraz 0) nie wiem/nie mam zdania.

Źródło: opracowanie własne na podstawie przeprowadzonych badań empirycznych.

Do najbardziej utylitarnych kanałów komunikacji przedsiębiorstwa z klientami w badanym procesie (por. tab. 5) zaliczyć należy przede wszystkim: kontakt osobisty $(\bar{x}=3,64)$, kontakt przez stronę www $(\bar{x}=3,16)$, targi, wystawy, pokazy i dni otwarte $(\bar{x}=2,97)$ oraz kontakt telefoniczny $(\bar{x}=2,95)$. Do kanałów, których przydatność różnicowana jest najczęściej ze względu na rolę interesariuszy $\left(n_{1}=5 / 5\right)$, zaliczają się kontakt osobisty oraz forum internetowe moderowane przez producenta. $Z$ kolei częstość różnicowania przydatności kanałów komunikacji w poszczególnych grupach interesariuszy jest najwyższa w grupach pracowników $\left(n_{2}=11 / 13\right)$, partnerów biznesowych oraz konkurentów $\left(n_{2}=10 / 13\right)$.

Ostatni obszar badawczy dotyczył oceny ważności wybranych czynników procesu współkreowania wartości w perspektywie roli badanych grup interesariuszy (por. tab. 6).

Tabela 6. Średnia ważność wybranych czynników procesu przygotowywania lub modyfikacji oferty przedsiębiorstwa wspólnie z klientami oraz częstość jej różnicowania ze względu na znaczenie interesariuszy

\begin{tabular}{|c|c|c|c|c|c|c|c|}
\hline \multirow{2}{*}{$\begin{array}{l}\text { Czynniki procesu } \\
\text { przygotowywania lub } \\
\text { modyfikacji oferty } \\
\text { przedsiębiorstwa }\end{array}$} & \multirow{2}{*}{ 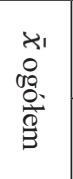 } & \multicolumn{5}{|c|}{ Interesariusze } & \multirow{2}{*}{ 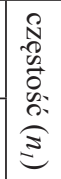 } \\
\hline & & pracownicy & klienci & dostawcy & $\begin{array}{l}\text { partnerzy } \\
\text { biznesowi }\end{array}$ & konkurenci & \\
\hline 1 & 2 & 3 & 4 & 5 & 6 & 7 & 8 \\
\hline $\begin{array}{l}\text { 1. ogólna ocena produktu przez } \\
\text { klienta }\end{array}$ & 3,34 & $\begin{array}{l}3,02 \\
3,43\end{array}$ & $\begin{array}{l}3,08 \\
3,52\end{array}$ & $\begin{array}{l}3,18 \\
3,44\end{array}$ & $\begin{array}{l}2,88 \\
3,42\end{array}$ & $\begin{array}{l}3,16 \\
3,45\end{array}$ & $5 / 5$ \\
\hline $\begin{array}{l}\text { 2. ocena parametrów } \\
\text { fizycznych lub technicznych } \\
\text { produktu przez klienta }\end{array}$ & 3,22 & $\begin{array}{l}2,88 \\
3,31\end{array}$ & $\begin{array}{l}3,00 \\
3,37\end{array}$ & - & $\begin{array}{l}2,91 \\
3,27\end{array}$ & $\begin{array}{l}3,05 \\
3,33\end{array}$ & $4 / 5$ \\
\hline $\begin{array}{l}\text { 3. określenie funkcjonalności } \\
\text { produktu przez klienta }\end{array}$ & 3,20 & $\begin{array}{l}2,79 \\
3,31\end{array}$ & $\begin{array}{l}2,94 \\
3,38\end{array}$ & $\begin{array}{l}3,00 \\
3,33\end{array}$ & $\begin{array}{l}2,65 \\
3,30\end{array}$ & $\begin{array}{l}2,97 \\
3,36\end{array}$ & $5 / 5$ \\
\hline
\end{tabular}




\begin{tabular}{|c|c|c|c|c|c|c|c|}
\hline 1 & 2 & 3 & 4 & 5 & 6 & 7 & 8 \\
\hline $\begin{array}{l}\text { 4. wyrażanie opinii dotyczących } \\
\text { produktu (informacja } \\
\text { zwrotna) ze strony klienta }\end{array}$ & 3,20 & - & - & $\begin{array}{l}2,94 \\
3,37\end{array}$ & $\begin{array}{l}2,74 \\
3,27\end{array}$ & - & $2 / 5$ \\
\hline $\begin{array}{l}\text { 5. ustalanie (ocena) korzystności } \\
\text { zakupu - relacji cena / jakość } \\
\text { produktu przez klienta }\end{array}$ & 3,15 & $\begin{array}{l}2,69 \\
3,28\end{array}$ & $\begin{array}{l}2,87 \\
3,34\end{array}$ & $\begin{array}{l}2,94 \\
3,29\end{array}$ & $\begin{array}{l}2,68 \\
3,23\end{array}$ & - & $4 / 5$ \\
\hline $\begin{array}{l}\text { 6. ocena przeznaczenia lub } \\
\text { przydatności produktu }\end{array}$ & 3,15 & $\begin{array}{l}2,65 \\
3,29\end{array}$ & $\begin{array}{l}2,89 \\
3,33\end{array}$ & $\begin{array}{l}2,97 \\
3,26\end{array}$ & $\begin{array}{l}2,76 \\
3,20\end{array}$ & $\begin{array}{l}2,95 \\
3,27\end{array}$ & $5 / 5$ \\
\hline $\begin{array}{l}\text { 7. ocena jakości, wytrzymałości } \\
\text { lub trwałości produktu przez } \\
\text { klienta }\end{array}$ & 3,09 & - & $\begin{array}{l}2,78 \\
3,31\end{array}$ & $\begin{array}{l}2,83 \\
3,28\end{array}$ & $\begin{array}{l}2,65 \\
3,17\end{array}$ & - & $3 / 5$ \\
\hline $\begin{array}{l}\text { 8. informacje dotyczące wcześ- } \\
\text { niejszych doświadczeń klienta }\end{array}$ & 3,03 & $\begin{array}{l}2,56 \\
3,14\end{array}$ & $\begin{array}{l}2,76 \\
3,19\end{array}$ & $\begin{array}{l}2,83 \\
3,13\end{array}$ & $\begin{array}{l}2,53 \\
3,09\end{array}$ & - & $4 / 5$ \\
\hline $\begin{array}{l}\text { 9. ocena gwarancji oraz serwisu } \\
\text { - sposobów rozwiązania } \\
\text { problemu klienta z nabytym } \\
\text { produktem }\end{array}$ & 2,88 & $\begin{array}{l}2,44 \\
2,99\end{array}$ & $\begin{array}{l}2,49 \\
3,15\end{array}$ & $\begin{array}{l}2,55 \\
3,10\end{array}$ & $\begin{array}{l}2,47 \\
2,94\end{array}$ & $\begin{array}{l}2,65 \\
3,02\end{array}$ & $5 / 5$ \\
\hline $\begin{array}{l}\text { 10. ocena poziomu kosztów } \\
\text { związanych z eksploatacją } \\
\text { produktu przez klienta }\end{array}$ & 2,85 & $\begin{array}{l}2,27 \\
3,00\end{array}$ & $\begin{array}{l}2,46 \\
3,12\end{array}$ & $\begin{array}{l}2,52 \\
3,06\end{array}$ & $\begin{array}{l}2,35 \\
2,92\end{array}$ & $\begin{array}{l}2,56 \\
3,03\end{array}$ & $5 / 5$ \\
\hline $\begin{array}{l}\text { 11. preferencje osobiste (nawyki) } \\
\text { klienta }\end{array}$ & 2,84 & $\begin{array}{l}2,35 \\
2,98 \\
\end{array}$ & $\begin{array}{l}2,60 \\
3,01\end{array}$ & $\begin{array}{l}2,63 \\
2,98\end{array}$ & - & - & $3 / 5$ \\
\hline $\begin{array}{l}\text { 12. ocena komfortu dokonywania } \\
\text { zakupów przez klienta }\end{array}$ & 2,68 & $\begin{array}{l}2,25 \\
2,80\end{array}$ & $\begin{array}{l}2,33 \\
2,93 \\
\end{array}$ & $\begin{array}{l}2,26 \\
2,98\end{array}$ & $\begin{array}{l}2,24 \\
2,75\end{array}$ & $\begin{array}{l}2,36 \\
2,90 \\
\end{array}$ & $5 / 5$ \\
\hline $\begin{array}{l}\text { 13. ocena promocyjnych działań } \\
\text { przedsiębiorstwa przez klienta }\end{array}$ & 2,60 & $\begin{array}{l}2,10 \\
2,73\end{array}$ & $\begin{array}{l}2,32 \\
2,78\end{array}$ & $\begin{array}{l}2,38 \\
2,73\end{array}$ & - & - & $3 / 5$ \\
\hline $\begin{array}{l}\text { 14. ocena usług dodatkowych } \\
\text { związanych z nabytym przez } \\
\text { klienta produktem }\end{array}$ & 2,59 & $\begin{array}{l}2,13 \\
2,71\end{array}$ & $\begin{array}{l}2,32 \\
2,77\end{array}$ & $\begin{array}{l}2,20 \\
2,87\end{array}$ & $\begin{array}{l}2,06 \\
2,68\end{array}$ & - & $4 / 5$ \\
\hline $\begin{array}{l}\text { 15. warunki finansowania zakupu } \\
\text { (różne formy płatności, } \\
\text { ewentualne kredytowanie } \\
\text { zakupu itp.) przez klienta }\end{array}$ & 2,58 & $\begin{array}{l}2,10 \\
2,71 \\
\end{array}$ & $\begin{array}{l}2,16 \\
2,88 \\
\end{array}$ & $\begin{array}{l}2,21 \\
2,84 \\
\end{array}$ & - & $\begin{array}{l}2,35 \\
2,72 \\
\end{array}$ & $4 / 5$ \\
\hline $\begin{array}{l}\text { 16. działania promocyjne } \\
\text { realizowane przez klienta } \\
\text { dotyczace producenta, marki } \\
\text { lub produktu }\end{array}$ & 2,57 & $\begin{array}{l}2,04 \\
2,71\end{array}$ & $\begin{array}{l}2,24 \\
2,80\end{array}$ & $\begin{array}{l}2,34 \\
2,71\end{array}$ & - & - & $3 / 5$ \\
\hline $\begin{array}{l}\text { 17. informacje o stylu życia klienta, } \\
\text { przynależności do subkultury } \\
\text { lub grupy społecznej }\end{array}$ & 2,16 & $\begin{array}{l}1,56 \\
2,33\end{array}$ & $\begin{array}{l}1,87 \\
2,36\end{array}$ & $\begin{array}{l}1,94 \\
2,31\end{array}$ & $\begin{array}{l}1,71 \\
2,24\end{array}$ & $\begin{array}{l}1,88 \\
2,35 \\
\end{array}$ & $5 / 5$ \\
\hline częstość różnicowani & $\mathrm{a}\left(n_{2}\right)$ & $15 / 17$ & $16 / 17$ & $16 / 17$ & $13 / 17$ & $9 / 17$ & \\
\hline
\end{tabular}

Legenda: pomiar dokonany na czterostopniowej skali Likerta, gdzie: 1) bardzo niska, 2) niska, 3) wysoka, 4) bardzo wysoka oraz 0) nie wiem/nie mam zdania.

Źródło: opracowanie własne na podstawie przeprowadzonych badań empirycznych. 
W zbiorze najważniejszych czynników procesu przygotowania lub modyfikacji oferty przedsiębiorstwa znajdują się: (por. tab. 6) ogólna ocena produktu $(\bar{x}=3,34)$, ocena parametrów fizycznych lub technicznych $(\bar{x}=3,22)$, określenie funkcjonalności produktu $(\bar{x}=3,20)$ oraz opinie i informacja zwrotna ze strony klienta $(\bar{x}=3,20)$. Do obszarów najczęściej różnicowanych ze względu na znaczenie interesariuszy $\left(n_{l}=5 / 5\right)$ zaliczają się: ogólna ocena produktu przez klienta, określenie funkcjonalności produktu, informacje o stylu życia klienta, ocena kosztów związanych z eksploatacją produktu oraz ocena warunków gwarancji i serwisu. Z kolei do grup interesariuszy, w zakresie których różnicowanie jest najczęstsze, zaliczają się klienci i dostawcy $\left(n_{2}=16 / 17\right)$, pracownicy $\left(n_{2}=15 / 17\right)$ oraz partnerzy biznesowi $\left(n_{2}=13 / 17\right)$.

Do obszarów współkreowania, w których zakresie różnicowanie badanych elementów ze względu na rolę interesariuszy jest najczęstsze, zaliczają się interakcje z klientami $\left(n_{l}=84 \%\right)$, determinanty procesu współkreowania wartości $\left(n_{l}=81 \%\right)$ oraz zasoby angażowane przez klienta $\left(n_{l}=80 \%\right)$. Natomiast częstość różnicowania w ramach poszczególnych grup interesariuszy jest najwyższa dla partnerów biznesowych $\left(n_{2}=74 \%\right)$, następnie dostawców $\left(n_{2}=68 \%\right)$, pracowników $\left(n_{2}=65 \%\right)$ i klientów $\left(n_{2}=63 \%\right.$; por. tab. 7$)$.

Tabela 7. Częstość różnicowania znaczenia obszarów procesu współkreowania wartości dla klienta ze względu na znaczenie interesariuszy

\begin{tabular}{|c|c|c|c|c|c|c|}
\hline \multirow{2}{*}{$\begin{array}{l}\text { Obszary procesu współkreowania } \\
\text { wartości dla klienta }\end{array}$} & \multicolumn{5}{|c|}{ Interesariusze } & \multirow{2}{*}{ 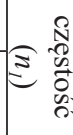 } \\
\hline & pracownicy & klienci & dostawcy & $\begin{array}{l}\text { partnerzy } \\
\text { biznesowi }\end{array}$ & konkurenci & \\
\hline $\begin{array}{l}\text { 1. składowe procesu } \\
\text { współkreowania wartości dla } \\
\text { klienta }\end{array}$ & $11 / 16$ & $11 / 16$ & $13 / 16$ & $10 / 16$ & $2 / 16$ & $59 \%$ \\
\hline $\begin{array}{l}\text { 2. interakcje z klientami w procesie } \\
\text { współkreowania wartości dla } \\
\text { klienta }\end{array}$ & $4 / 5$ & $4 / 5$ & $3 / 5$ & $5 / 5$ & $5 / 5$ & $84 \%$ \\
\hline $\begin{array}{l}\text { 3. zasoby klienta w procesie } \\
\text { współkreowania wartości dla } \\
\text { klienta }\end{array}$ & $8 / 10$ & $8 / 10$ & $9 / 10$ & $9 / 10$ & $6 / 10$ & $80 \%$ \\
\hline $\begin{array}{l}\text { 4. ryzyko związane z procesem } \\
\text { współkreowania wartości dla } \\
\text { klienta }\end{array}$ & $3 / 12$ & $5 / 12$ & $7 / 12$ & $12 / 12$ & $9 / 12$ & $60 \%$ \\
\hline $\begin{array}{l}\text { 5. kanały komunikacji } \\
\text { przedsiębiorstwa z klientem }\end{array}$ & $11 / 13$ & $6 / 13$ & $6 / 13$ & $10 / 13$ & $10 / 13$ & $66 \%$ \\
\hline $\begin{array}{l}\text { 6. determinanty procesu } \\
\text { współkreowania wartości dla } \\
\text { klienta }\end{array}$ & $15 / 17$ & $16 / 17$ & $16 / 17$ & $13 / 17$ & $9 / 17$ & $81 \%$ \\
\hline częstość różnicowania $\left(n_{2}\right)$ & $65 \%$ & $63 \%$ & $68 \%$ & $74 \%$ & $51 \%$ & \\
\hline
\end{tabular}

Źródło: opracowanie własne na podstawie przeprowadzonych badań empirycznych. 
Uzyskane wyniki jednoznacznie wskazują na prawidłowość, zgodnie z którą w przedsiębiorstwach definiujących rolę interesariuszy jako dużą lub kluczową znaczenie elementów składających się na proces współkreowania wartości dla klienta jest zdecydowanie wyższe. W przypadku tych organizacji wskazywać to może na świadomość budowania relacji z różnymi interesariuszami, co stanowi istotę badanego procesu - odejście od jednostronnego tworzenia wartości przez przedsiębiorstwo w stronę rozwiązań sieciowych. Współkreowanie wartości dla klienta stało się możliwe przede wszystkim dzięki rozwojowi technologii internetowych, powstaniu społeczeństwa sieciowego oraz zjawisku „otwartych innowacji”, co powoduje przeniesienie na rynki B2C relacji typowych wcześniej dla rynków B2B. Powoduje to również, że dotychczasowe, tradycyjne role interesariuszy ulegają zmianom [Frow i in. 2015] i z podmiotów o wyspowym charakterze stają się systemami wymieniającymi zasoby [Storbacka i in. 2015] oraz realizującymi cele, zarówno konkurencyjne, jak i wspólne.

\section{Zakończenie}

Analiza uzyskanych wyników pozwala zarówno na hierarchizację (określenie ważności) elementów składających się na wyodrębnione obszary procesu współkreowania wartości dla klienta, jak i na określenie częstości różnicowania tych elementów ze względu na rolę interesariuszy - pracowników, klientów, dostawców, partnerów biznesowych oraz konkurentów. Uzyskane wyniki stanowić mogą podstawę rozwiązywania konkretnych problemów decyzyjnych, zwłaszcza w przypadku menedżerów odpowiedzialnych za budowę strategii zarządzania interesariuszami w organizacjach współkreujących wartość dla klienta.

Prezentacja uzyskanych wyników wymaga uzupełnienia o dodatkowe badania i analizy, których celem powinna być bardziej szczegółowa analiza znaczenia interesariuszy w procesie współkreowania wartości dla klienta. Powinno to pozwolić na określenie rekomendacji utylitarnych w rozwiązywaniu konkretnych problemów decyzyjnych.

\section{Bibliografia}

Berry L.L., 1981, The employee as customers, Journal of Retail Banking, no 3 (3).

Dąbrowski T.J., 2015, Marketing - między koncentracja na kliencie a orientacją na interesariuszy, Handel Wewnętrzny, nr 5 (358).

Doyle P., 1995, Marketing in the New Millenium, European Journal of Marketing, no 29 (13).

Doyle P., 2008, Value-Based Marketing. Marketing Strategies for Corporate Growth and Shareholder Value, John Wiley \& Sons, Chichester.

Ehlen C., van der Klink M., Stoffers J., Boshuizen H., 2017, The Co-Creation-Wheel: A four-dimensional model of collaborative, interorganisational innovation, European Journal of Training and Development, vol. 41, Issue 7.

Frow P., Nenonen S., Payne A., Storbacka K., 2015, Managing co-creation design: a strategic approach to innovation, British Journal of Management, vol. 26, no 3. 
Gouillart F.J., 2014, The race to implement co-creation of value with stakeholders: five approaches to competitive advantage, Strategy \& Leadership, vol. 42, Issue 1.

Grandy G., Levit T., 2015, Value co-creation and stakeholder complexity: what strategy can learn from churches, Qualitative Research in Organizations and Management: An International Journal, vol. 10 , Issue 3.

Ind N., Coates N., 2013, The meanings of co-creation, European Business Review, vol. 25, no 1.

Kennedy E., 2017, I create, you create, we all create - for whom?, Journal of Product \& Brand Management, vol. 26, Issue 1.

Payne A., Holt S., 1999, Diagnosing Customer Value: A Review of the Literature and a Framework For Relationship Value Management, Cranfield Working Paper Series, Cranfield School of Management, Cranfield.

Payne A., Storbacka K., Frow P., Knox S., 2009, Co-creating brands: diagnosing and designing the relationship experience, Journal of Business Research, vol. 62, no 3.

Piwoni-Krzeszowska E., 2013, Zarządzanie wartościa relacji przedsiębiorstwa z rynkowymi interesariuszami - aspekt organizacyjnego uczenia się na przykładzie „,SPOŁEM” PSS w Lubaniu, Prace Naukowe Uniwersytetu Ekonomicznego we Wrocławiu, nr 310.

Prahalad C., Ramaswamy V., 2004, Co-creation experiences: the next practice in value creation, Journal of Interactive Marketing, vol. 18, no 3.

Priem R.L., 2007, A consumer perspective on value creation, Academy of Management Review, vol. 32 , no 1 .

Rampen W., 2014, My personal definition of business with customer value co-creation, http://www.customerthink.com (styczeń 2014).

Roser T., DeFillippi R., Samson A., 2013, Managing your co-creation mix: co-creation ventures in distinctive contexts, European Business Review, vol. 25, Issue 1.

Storbacka K., Frow P., Nenonen S., Payne A., 2015, Designing Business Models for Value Co-Creation, [w:] Vargo S., Lusch R. (red.), 2012, Special Issue - Toward a Better Understanding of the Role of Value in Markets and Marketing, Review of Marketing Research, vol. 9.

Vallaster C., von Wallpach S., 2013, An online discursive inquiry into the social dynamics of multi-stakeholder brand meaning co-creation, Journal of Business Research, vol. 66, no 9.

Vargo S., Lusch R., 2004, Evolving to a new dominant logic for marketing, Journal of Marketing, vol. 68 , no 1 .

Wieczorkowska G., Wierzbiński J., 2011, Statystyka od teorii do praktyki, Wydawnictwo Naukowe Scholar, Warszawa. 